\title{
THE USE OF AUDIO VISUAL VIDEO MEDIA ON UNDERSTANDING THE CONCEPT OF DISASTER MITIGATION OF GEOGRAPHIC EDUCATION STUDENTS OF VETERAN BANGUN NUSANTARA SUKOHARJO UNIVERSITY
}

\author{
Muh Husyain Rifai \\ Geography Education, Veteran Bangun Nusantara Sukoharjo University \\ email: husyain.rifai@gmail.com
}

\begin{abstract}
The learning of Disaster Mitigation Material needs to be given to student teacher's candidate, so the college students have the understanding about the importance of disaster Mitigation because Indonesia is included in the Pacific Ring of Fire. This research aims to analyze the understanding of disaster mitigation concept of students before and after given learning material by using Audio Visual Video media to the early level college students. This uses quantitative research with an experimental approach. The population on this research are college students at semester 1 \& 3 of Geography Education in the odd semester of 2017/2018 academic year with 24 participants. The data collecting techniques use test, student's worksheet and questionnaire. Data analysis technique uses normality test statistic, homogeneity and T test with the aid of SPSS statistic 21. The results of this research shows that 1) there are differences in the results of student's understanding of mitigation concepts by using audio-visual video media before and after treatment, 2) by using video, students give a positive respond on the learning process.
\end{abstract}

Keywords: video, concept understanding, disaster mitigation

\section{INTRODUCTION}

Recently there are a lot of disasters occur in Indonesia started in Earthquake (Sukabumi), Flood (Medan and Yogyakarta), Deluge (Pacitan and East Lombok), Volcanic eruption (Agung mountain, Bali), Tornado (Sidoarjo), and some other disasters that occur in unpredictable weather. These happen because Indonesia is part of an archipelago which is geographically located among three large plates (Eurasian, Indo-Australian and Pacific). So, this country is susceptible to natural disaster. In addition, Indonesia is also included in the ring of fire zone so that the possibility of disaster may occur.

Indonesia is an archipelago with high disaster potential especially earthquake, volcanic eruption, tsunami because this country is located at the junction of three active plates/crust. The three active plates are Indo-Australian plate in the south, Eurasian plate in the north, and Pacific plate in the east. These plates move and collide each other so that Indo-Australian plate plunges under Eurasian plate. The subduction of the Indo-Australian plate moving to north with Eurasian plate moving to south creates an earthquake pathway and a series of active volcanoes. This is clearly described by Mister and Jordan (1978), explaining that Southeast Asia is moving $1 \mathrm{~cm} /$ year to the north while the IndianAustralian Ocean plate is moving $7 \mathrm{~cm} /$ year to the north, and Pacific plate is moving $9 \mathrm{~cm} /$ year to the west. There are many datum have been obtained since the advent of Positioning Global System (GPS) (Verstappen, 2000: 17)

According to the sources above, it can be assumed that we are impossible to avoid the disaster. What we can do is how we can live side by side with disaster prone areas. By the law No. 24 of 2007 about Disaster Management, there is a significant change towards disaster management efforts in Indonesia both of national and district levels. If the disaster management effort in Indonesia is only an emergency response, through the law No. 24 of 2007 covers all phases of disaster started by mitigation phase, preparedness, emergency response to post-disaster recovery. There is a change of paradigm from emergency response to disaster preparedness that disaster is no longer considered something that must 
be taken for granted. However, it can be anticipated and reduce the victim also minimize the impact of disaster.

It is necessary for the government to increase socialization about disaster risk reduction/disaster mitigation trough education. School as educational institution should not only provide transfer of knowledge but also must be able to provide facilities and skills for student's survival when they are already involved in society. Students are the ones who most quickly transfer the knowledge from school to their family and community. Therefore, empowering school's students and college's students to understand disaster mitigation is the first step in building a disaster-aware society. So, when disaster occurs students, teachers, and societies are no longer being confused or panic because they understand how to reduce disaster risk.

In this case, the right media is needed to implant disaster mitigation accordance the need and student's characteristic. The early implant of disaster mitigation in school can be conducted by using the help of illustrated story, simulation exercise, or inserting disaster mitigation materials into appropriate subject. Empowering children from an early age to understand disaster mitigation is the first step in building a disaster-aware society.

The process of this research uses audio-visual media in the form of audio-visual video media. This aims to bring learning resources into the classroom. Learning resources that are presented to the classroom are intended to replace existing learning resources in the field, but students can see these learning resources clearly. Prasetya (2004, page 160) states that: audio visual video media is a medium that has sound and image elements, so hearing and sight are needed to enjoy them. This media is divided into silent audio visuals (sound slides, audio series films, voice print) and motion audio visuals (sound films, video cassettes).

Audio-visual video media is one of the learning media that can improve student's memory. Based on research of the ability to remember conducted by Sovocom Company in America, The following concludes (Prasetya, 2014, page 48); (1) Verbal (writing) 20\%; (2) Audio only 10\%; (3) Visual only 20\% (4) Audio visual 50\%.

\section{METHOD}

The method used in this study is Quasi Experiment. McMillan and Schumacher (2001, p.51) argue that usefulness of quasi-experimental method is similarity to determine casual and direct manipulation condition. Population and research sample were 24 students of geography education semester 1 and 3 of the Faculty of Teacher Training and Education in the odd semester of 2016/2018 academic year. The taking student's population in semester 1 and 3 was based on the fact that students in semester 1 and 3 were the new students based on the interview checks that they had never received Disaster Mitigation material before.

\section{RESULTS}

Through the use of Audio Visual Video media by displaying various videos of forms of natural disasters that occur in the world, it is able to provide information about the form of disasters that occur and how to respond when disasters occur. Natural Disaster Videos displayed in front of students include; (1) Natural Geological Disasters, including Tsunami, Earthquake, Volcanic, and landslide; (2) Meteorological natural disasters, covering flood, drought, and global warming; (3) Extra-terrestrial natural disaster that occurs outside of space. 


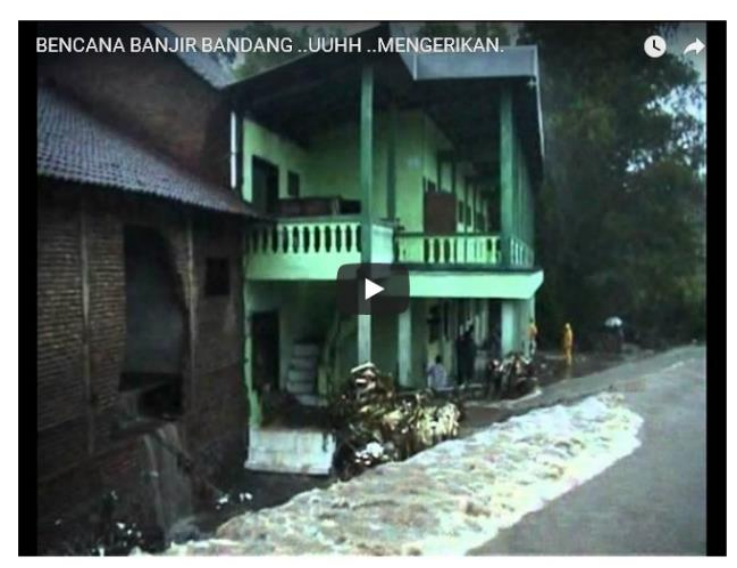

Picture 1. Geological Natural Disaster Video

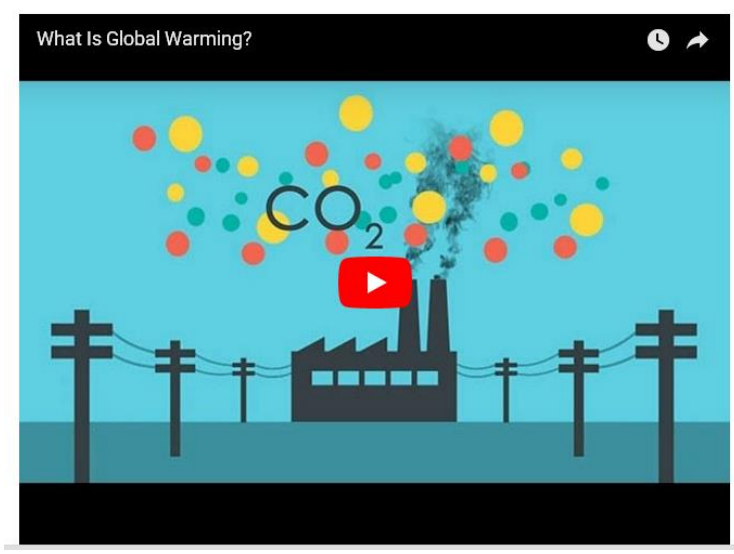

Picture 2. Meteorological Natural Disaster Video



Picture 3. Earthquake Disaster Mitigation Stage Video

The result of the research explains how the effect of audio-visual media in the form of video on understanding the concept of disaster mitigation showed that the understanding of the concept of disaster mitigation has increased where in the initial test the average value obtained is 44.3318 . The standard deviation is 11.627. From 24 students, 1 person obtains a maximum score of 63.64 while the minimum score 18.18 is 1 person. In the final test, after being given treatment, the average value is 67.992. The standard deviation is obtained is 13.088 . From 24 students, 1 person obtains a maximum score 86.36 while the minimum score 27.27 is 1 person. The comparison of the results of the pre-test and final test in the control class can be seen in the following table; 
Table 1. Comparison of Pre Test and Post Test

\begin{tabular}{|c|c|c|c|c|c|c|}
\hline Treatment & $\begin{array}{c}\text { The } \\
\text { Average } \\
\text { value of } \\
\text { Test Results }\end{array}$ & $\mathbf{N}$ & $\begin{array}{l}\text { Standard } \\
\text { Deviation }\end{array}$ & $\begin{array}{c}\text { The } \\
\text { Change }\end{array}$ & $\begin{array}{l}\text { Gain } \\
\text { Value }\end{array}$ & Information \\
\hline Pre Test & 44,318 & 24 & 11,628 & 60,2 & 0,43 & moderate \\
\hline Pos Test & 67,998 & 24 & 14,088 & & & \\
\hline
\end{tabular}

Source: the Results of Data Processing 2017

The change in the score for understanding the concept of disaster mitigation in the initial test and in the final test obtained by students is $60,111 \%$ with a gain value of 0.43 in the category moderate concept understanding improvement. The normality test required is only a normality test. Normality test is fulfilled if the test results are not significant for a certain level of significance ( $\alpha$ ) (usually $\alpha=$ 0.05 or $\alpha=0.01$ ). Conversely, if the significance test results are equal to or less than $\alpha$ or $\alpha<0.05$, then the normality of the data is not fulfilled.

Based on the test results on the pre-test, it is obtained a significance value of 0.001 . The pretest has a significance value less than $\alpha=0.05$ and it can be concluded that the data is not normally distributed. The final test obtains a significance value of 0 . This test has a significance value less than $\alpha=0.05$. Therefore, it can be concluded that the two datum are not normally distributed. While the homogeneity test is fulfilled if the test results are not significant for a certain level of significance $(\alpha)$ (usually $\alpha=0.005$ or 0.01 ). Conversely, if the result of significance test is less than or equal to $\alpha$ it is considered not fulfilled.

Based on the test results, the significance value is obtained in the pre-test and final test. The pre-test obtains a significance value of 0.001 . The final test obtains a significance value of 0 . It turns out that both test had a significance value less than $\alpha=0.05$. It can be concluded that two tests are not homogeneous. The results of the normality and homogeneity tests that have been done, the pre-test is normally distributed and the post-test is not normal. As for the homogeneity of the data, both of them are not homogeneous. Therefore, hypothesis testing is carried out by using a non-parametric statistical test, namely Mann-Whitney $U$ test. The determination of acceptance of the hypothesis is indicated by the sig value. (2-tailed). If the significance value $>0.05$, then $\mathrm{H}_{0}$ is accepted, on the other hand if the the significance value $<0.05$ then $\mathrm{H}_{0}$ is rejected (Gunawan, 2013, page 118). 
Table 2. Pretest-Posttest Mann-Whitney Test Results

\begin{tabular}{cc}
\hline \multicolumn{2}{c}{ Statistics $^{\text {a }}$ Test } \\
& Prepost Control \\
\hline Mann-Whitney $U$ & 59,000 \\
\hline Wilcoxon $W$ & 359,000 \\
\hline Z & $-4,744$ \\
\hline Asymp. Sig (2-tailed) &, 000 \\
\hline
\end{tabular}

Table 2 shows that the Mann-Whitney $U$ value is 59 with a $\mathrm{Z}$ value of -4.744 and a significance value (2-tailed) of 0.000 turns $\alpha$ is bigger than the significance value (2-tailed) or $0.05>0.000$, So $\mathrm{H}_{0}$ os rejected and $\mathrm{H}_{2}$ is accepted. Based on this calculation, it is concluded that there are some differences in the results of student's understanding of the concept of disaster mitigation tests using audio-visual video media before and after treatment. The results of the calculations show that learning by using audio-visual video media can improve student's understanding of disaster mitigation concept. After being given treatment, a significant change in value is obtained between the results of the initial test and the final test with a gain score of 0.430 which is categorized as moderate. This shows that the delivery of disaster mitigation material can be done by using video as in intermediary to present learning resources to students, it tends to be able to develop geographic cognitive partners and strengthen student's understanding of material in the context of disaster mitigation.

\section{CONCLUSION}

Based on the problem formulations and evidence results, there are several things can be concluded that; (1) There are differences in the results of student's understanding of mitigation concepts by using audio-visual video media before and after treatment; (2) Learning by using video has increased the understanding of the concept of disaster mitigation. However, the increase is only in a moderate concept; (3) Students give positive responses to the material activities presented, this can be seen from the enthusiasm of students in the lecture process; (4) The use of audio-visual video media in the learning process can save time and more economical regarding the distance of learning resources. 


\section{BIBLIOGRAPHY}

Anitah, Sri. (2010). Media Pembelajaran. Surakarta: Yuma Pustaka.

Arsyad, Azhar. (2007). Media Pembelajaran. Jakarta: RajaGrafindo Persada.

Gatut Priyowidodo. (Vol.13 No. .Januari 2013, hlm 47-61). Literasi Mitigasi Bencana Tsunami Untuk Masyarakat Pesisir Di Kabupaten Pacitan Jawa Timur. JURNAL EKOTRANS. Padang; Pusat Studi Ekonomi dan Sosial Lembaga Penelitian \& Pengabdian Masyarakat Universitas Ekasakti.

Gunawan, A. M. (2013). Statistik untuk Penelitian Pendidikan. Yogyakarta: Parama Publishing. http://pgsd.uad.ac.id/pentingnya-penanaman-mitigasi-bencana-sejak-dini.

McMillan, H.J. \& Schumacher, S. (2001). Research in Education a Conceptual Introduction. New York \& London: Longman.

Prasetya, P. S. (2014). Media Pembelajaran Geografi. Yogyakarta: Ombak.

Purwanto, Edy. (2014). Strategi Pembelajaran Bidang Studi. Yogyakarta: Ombak.

Sudjana, N. \& Rivai, A. (2013). Media Pengajaran. Bandung: Sinar Baru Algensindo.

Sumaatmadja, Nursid. (1997). Metodologi Pengajaran Geografi. Jakarta: Bumi Aksara.

Syamsul Maarif. (Vol 3 No 1 Tahun 2012).Konsistensi Pengetahuan dan Pemaknaan Tentang Ancaman

Bencana Alam (Studi Kasus Ancaman Bencana Gunung Merapi) JURNAL PENANGGULANGAN BENCANA. Jakarta: Pusat Data Informasi dan Humas Badan Nasional Penanggulangan Bencana. 